\title{
濁度自動測定装置についで
}

菱田耕造** 小泉宗三郎 ${ }^{* *}$ 西山勝暢 ${ }^{* *}$

\section{On the Automatic Turbidity Measuring Instrument}

\author{
Kozo Hishida, Sozaburo Koizumi and Katsunobu Nishiyama
}

\begin{abstract}
When a continual measurement of turbidity in the sea water is automatically carried out by the use of the submarine detector measuring the attenuation rate of parallel light beam through the water, it seems generally that water-tight cases containing the light source and the light receiver are apt to become dirty for a while in the sea water. To avoid such a trouble even a little, an instrument suitable for the automatic determination of turbidity has been devised by the authors. The principle employed is the measurement of scattered light intensity through the water as well as that of attenuated light intensity. And thus, the light receiver consists of a photo conductive cell at the centre and the surrounding twelve cells for the attenuated light and the scattered light respectively. Some results and considerations are represented with this new type turbidity meter, which may be considered applicable for some practical purposes.
\end{abstract}

\section{1. 緒 論}

海水中の䯚濁物を定量的に求めるためには，い ろいろな方法が考学られてきたが，連続測定によ り自記記録の形として求める場合には幾多の制約 を受け実用に供せられるものは比較的少ない，海 水を汲みあげてろ過する方法は機構的に煩雑さを 伴うから，光を用いる方法が適当であるが，光源 部, 受光部に使用するガラスが連続測定に際して, 海水中の懸濁物などによって污され，精度が著し く悪化する恐れがある。

元来, 光が海水中の懸濁物にあたるとき光は吸 収と散乱を受けるが，これを厳密に定量的に求め よ5とすると, いろいろな海水の光学的性質に応 じ, 適当な測定器械を用いなければならない。 (TYLER and PREISENDORFER，1962）ただ実用 的に海水中の懸濁物の量を光学的方法により求め るためには, 水中一定距離を通過した際の光の減 光の割合を測定する方法が主として用いられてき

* 1968年 9 月 2 日受理

** 気象研究所 Meteorological Research Institute
た、ところがこの際生ずるガラスの污れは連続観 測の場合には直ちに結果を無意味にするから，多 少厳密さにかけるところはあっても, 散乱光を同 時に測定し, 直達光との関連に和いて, 海水の濁 度が求められるならば少しでもこのような欠点は さけ得るのではないかと考えて，本装置を試作し た。

\section{2. 䒾 置}

海水中の懸濁物による散乱光は海水中の直達光 に比べ, はなはだ微弱であるために, 得られた光 電流を増幅したり，自然光を防ぐことに留意しな ければならない。そこで, 直達光の測定用受光器 を入れた水密のケース内で，これを光の平行光束 の方向に動かせるようにし, その距離に応じて生 ずる直達光量の変化から，間接的に散乱光の大き さを求める方法を最初試みたが，精度の点に沶い て低濁度の際不十分であり，また受光器の移動を 遠隔操作させることは機構上厄介であるから，直 接散乱光を求める方法を採用した。

濁度測定装置は水中所定の深さに置いた 濁度検 
light source

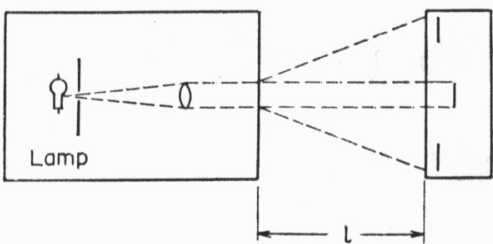

Fig. 1. A schematic representation of the detector.

出部とこれからとりた゚した光電流の電気的信号を 海上または陸上で自記記録させる部分とからなり たつ、検出部は Fig. 1 のよ5に光源部と受光部 とにわかれ，この間の距離は濁度の大きたに応じ て変壳られるよ5にした。光源部は光源ランプと レンズにより直径 $2 \mathrm{~cm}$ の平行光束を送り出させ るものであるが, 光源の明るさの変動を知るため の受光体 1 個を入れた.な抦定電圧装置により明 るさは一定にするようにしてある。

受光部は直径 $2 \mathrm{~cm}$ の円形の光導電セル $(\mathrm{Cd}-$ $\mathrm{Se}$ ）を中央に直達光測定用として，そのまわりに 同一の光導電セル 12 個を散乱測定用として配置し た。後者はドーナッ型の一体のものを採用する場 合に比べ，偏光フィルターをとり付けると縦横の 偏光がわかり，また直達光と散乱光の光量の比が たやすくわかるなどの点有利であろう。な扰，表 層近くの観測では光源ランプからの人工光に比 ベ, 自然光を極度に㧤さる必要があるので, 長 波部のみを通す赤色フィルターを用いたり，また 通水を妨げないで，光の迷入を防ぐような括拉い をとり付けるなどの工夫を試みた。(Fig 2) 以上濁 度装置の5ち, 主として検出部についての述べた

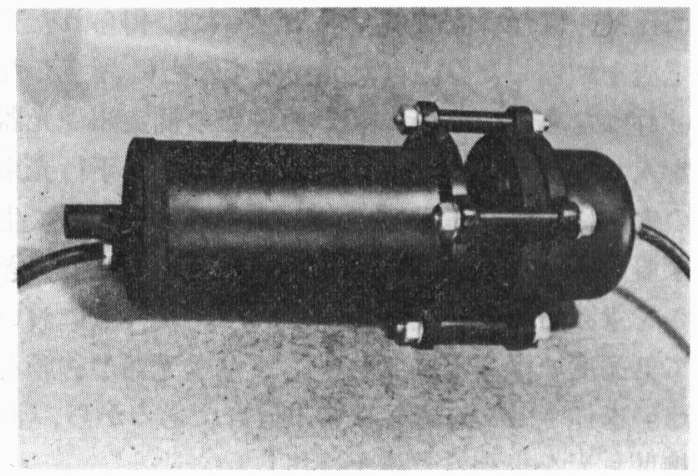

Fig. 2. The submarine detector of the turbidity meter.
が，送信や自記記録などについては特に新しいこ とはないのでここでは省略する。なお，製作を東 邦電探に依頼した。

\section{3. 考察}

Fig. 3 に㧍いて, 海水の光の減衰係数を $\tau$ とす ると,

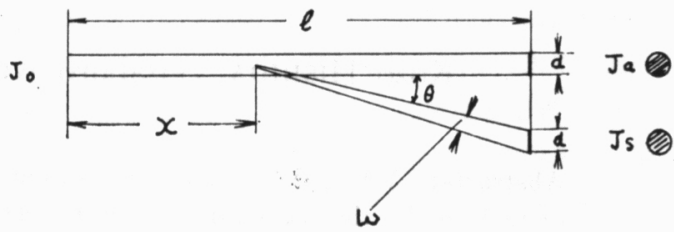

Fig. 3. Geometric relations between incident light, attenuated light and scattered light.

$$
J_{a}=J_{0} e^{-\tau l}
$$

ここに $J_{0}$ は光源に拈ける平行光束 (円形で直径 は $d$ とす）の光の強さで, $J_{\alpha}$ は $l$ なる長さの海 水を通過した後の直達光の強さである. また, 散 乱光を受ける受光体の一つでは, 受光体も平行光 束と同じく直径 $d$ とすると，近似的には

$$
J_{s}=J_{0} \int_{0}^{l} \beta_{\theta}(x) \omega(x) d x
$$

により, 受光体における光の強さ $J_{s}$ が求まる.こ こに $\beta_{0}$ は直達光と散乱光のなす角 $\theta$ 方向におけ る体積散乱関数, $\omega$ は散乱光の受光面積に対する 立体角であって, ともに光源と受光体間の距離 $x$ の関数であり， $\beta_{\theta}$ は全散乱係数 $\beta$ と次式により関 係づけられるものである。

$$
\beta=2 \pi \int_{0}^{\pi} \beta_{\theta} \sin \theta d \theta
$$

今, 海水中に打忊光の減衰の5ちで吸収と散 乱とによるものが一定の割合をしめると仮定する と $\tau \fallingdotseq k_{1} \beta$ ，また $l$ を一定としておくと

$$
\int_{0}^{l} \beta_{\theta}(x) \omega(x) d x \fallingdotseq k_{2} \beta
$$

と拈ける.こに $k_{1} ， k_{2}$ は常数とする. 従って(1)， (2) は

$$
\begin{aligned}
& J_{a} / J_{0}=e^{-k_{1} \beta l} \\
& J_{s} / J_{0}=k_{2} \beta
\end{aligned}
$$

とかける.（1') (2')の 2 式から, $J_{s} / J_{a}$ は $\beta$ の久 の函数となり光源部におけ容器のガラスが少々よ 


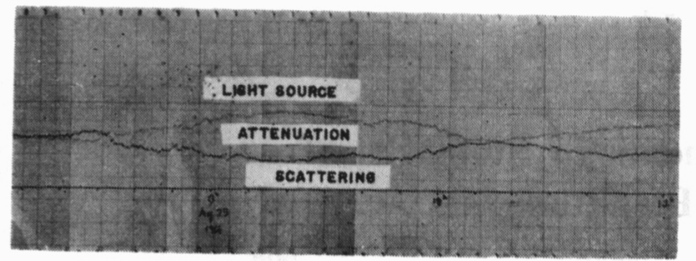

Fig. 4. An example of self-records showing variations in light intensities.

ごれたり電源が変動しても，これには関係がなく なり, また直達光のみによる場合よりも濁度は詳

\section{しく得られる.}

海水中に本検出部をつけて長期観測を行なった 記録について，その 1 例を Fig. 4 に掲げる. 光 源の明るさは汪とんど一定しており, 直達光, 散 乱光はともに変動している。な和直達光は散乱光 とは逆の位相になるが,これは $\left(1^{\prime}\right)$ 及び $\left(2^{\prime}\right)$ か ら知られる通りである. 更に, 直達光と散乱光の 関係を明らかにするために，広島湾に拊ける長期 観測の弓ち，1966年10月における 2 時間ごとの濁 度について, 相対応する直達光と散乱光のそれぞ れの值を片対数方眼紙に示した図 (Fig. 5) を掲

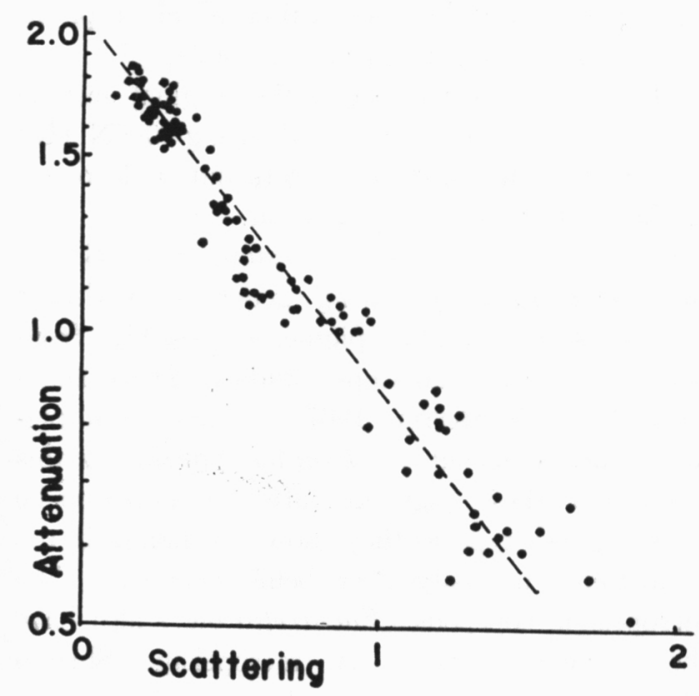

Fig. 5. The relation of scattered light intensity to attenuated light intensity plotted in a semi-log paper.
げる. 元来, 海水中の懸濁物はいろいろな組成や 形状をもったものの集合であるから，理論的に非 常に複雑な考察を必要とするにもかかわらず, 上 記に示した $\left(1^{\prime}\right),\left(2^{\prime}\right)$ 式はもっとも単純に考光た 近似式であるから，これらの点がばらつくのは当 然なことであろう。然しながら, 両者の間にはか なりよい相関が見られ，これらの式もある程度の 具体性をもつものと考觉てよい。

濁度を定量的に表現する仕方は未だ必ずしも一 定しているとはいえないが，上水道の水の濁度で 行なわれているような白陶土 $1 \mathrm{mg}$ を純水 $1 l$ 飞溶 かしたものを $1 \mathrm{ppm}$ とする決め方を用いて，10 ppm の範囲内で散乱光の強さを本装置で測ると, 濁度に正比例することが実験的にわかったので， これを一つの検定法として採用してきた。ただ， 白陶土を用いることは果して海水の濁度に適当で あるかどうかには問題点も多く, 特によい考光も ないので，例壳ばさきに示した Fig. 5 の諸点を 通るよらな直線を引いて (仮りに点線のように), この直線と縦軸との交点に扣ける直達光の值を基 準として，(1') 式によりそれぞれの全散乱係数を 求め, 海水の濁度を決める方法もかなり合理性が あると考觉らる。

\section{5. あとがき}

この研究は昭和39年より41年までの 3 か年間に わたる科学技術庁特別研究促進調整費による沿岸 海湾の海象に関する総合研究の一部であって, 観 測結果については別に報告する予定である。本装 置が厳密にはいろいろな問題点もあり, また, 細 部に改良すべき点は多々あるとしても, 一応実用 に供せられる段階に至ったと考克，ここに報告す る次第であって, 関係の各位に深甚な謝意を表す る.

\section{文献}

Tyler, J. E., and R. W. Preisendorfer (1962): In M. N. Hill [ed.], The sea, V. I. Interscience, New York and London, p. 397-451. 